\title{
Analisis Neraca Air di Pulau Jawa-Bali sebagai Upaya Antisipasi Krisis Air
}

\section{(Water Balance Analysis at Java-Bali Island for Anticipating Water Crisis)}

\author{
Nurul Chairunnisa ${ }^{*}$, Chusnul Arif ${ }^{1}$, Perdinan $^{2}$, dan Arif Wibowo ${ }^{3}$ \\ ${ }^{1}$ Departemen Teknik Sipil dan Lingkungan, Fakultas Teknologi Pertanian, Institut Pertanian Bogor. \\ J1. Raya Dramaga, Kampus IPB Dramaga, PO BOX 220, Bogor, Jawa Barat, Indonesia \\ 2 Departemen Geofisika dan Meteorologi, Fakultas Matematika dan Ilmu Pengetahuan Alam, \\ Institut Pertanian Bogor. \\ Jl. Raya Dramaga, Kampus IPB Dramaga, PO BOX 220, Bogor, Jawa Barat, Indonesia \\ ${ }^{3}$ Sub Direktorat Identifikasi dan Analisis Kerentanan, Direktorat Adaptasi Perubahan Iklim, Kementrian \\ Lingkungan Hidup dan Kehutanan Republik Indonesia. \\ Jl. Gatot Subroto, Gedung Manggala Wanabakti Blok 1 1t. 3, Jakarta, Indonesia \\ *Penulis Korespondensi: nurulchairunnisa5898@gmail.com
}

Diterima: 25 Maret 2021

Disetujui: 20 Juli 2021

\begin{abstract}
Water is one of the basic necessities used by living things on this earth. Along with the population growth with climate change, there are several cases of water crisis in Java and Bali, especially in the dry season. The purpose of this research is to project water demand and availability based on climate change scenarios, develop an analysis model for the impact of climate change on the water sector based on the water balance, and calculate environmental economic losses resulting from water deficit losses. The type of scenario used in climate analysis is RCP (Representative Carbon Pathway) 4.5 with two types of models. Provinces experiencing very critical water conditions in the 2021-2050 period using the CSIRO model are DKI Jakarta, East Java and Bali, with water criticality indexes of 296.25\%, 113.88\% and 123.64\%, with a water deficit loss of IDR 1.2 billion, IDR 7.93 billion and IDR 0.87 billion. Whereas with the MIROC model, the areas that have very critical water conditions are DKI Jakarta Province with a water criticality index of $220.36 \%$, with a water deficit loss of IDR 0.42 billion.
\end{abstract}

Keywords: Water Crisis, Water Balance, Climate Change, RCP 4.5

\section{PENDAHULUAN}

Kebutuhan pokok yang paling utama dibutuhkan oleh makhluk hidup di bumi ini yaitu air. Manusia merupakan makhluk hidup yang sangat bergantung dengan air, tidak hanya untuk memenuhi kebutuhan domestik rumah tangga, namun untuk kebutuhan lainnya seperti kebutuhan produksi dan kebutuhan industri. Seiring dengan bertambahnya waktu, jumlah populasi manusia berbanding lurus dengan kebutuhan airnya. Sedangkan menurut siklus hidrologi, jumlah air yang tersedia akan tetap. Berdasarkan hal tersebut, akan menimbulkan permasalahan dikemudian hari, yaitu terjadinya krisis air (Amalia \& Sugiri 2014).

Salah satu hal yang pengaruh terhadap keberlangsungan bumi ini yaitu iklim. Iklim yang dapat memberikan dampak memiliki komponen diantaranya curah hujan dan suhu. Kedua hal tersebut sangat berpengaruh terhadap ketersediaan air yang dibutuhkan bagi semua kalangan. Pola hujan yang terjadi menyebabkan suplai air yang berada pada tanah berfluktuatif (Haditiya \& Projono 2018). Suhu udara yang 
mengalami peningkatan yang diakibatkan oleh pemanasan global yaitu perubahan iklim mengakibatkan terjadinya proses penguapan atau evaporasi sehingga menyebabkan air tanah menyusut atau berkurang (Amalia \& Sugiri 2014).

Dampak perubahan iklim yang terjadi dapat diketahui dengan adanya peningkatan frekuensi kejadian iklim yang dapat menyebabkan banjir dan kekeringan. Adanya kejadian iklim dikenal dengan ENSO (El-NinoSouthern-Oscillation) yang didasarkan pada kejadian El Nino dan La Nina yang berdampak kepada distribusi curah hujan, khususnya di Indonesia. Peristiwa El Nino ditandai dengan peristiwa kekeringan, sedangkan La Nina ditandai dengan peristiwa banjir (Perdinan 2014).

Peristiwa perubahan iklim yang tidak mudah diperkirakan, dapat mempengaruhi beberapa hal. Berdasarkan hal tersebut, salah satunya wilayah yang terkena dampaknya yaitu Pulau Jawa. Pulau Jawa merupakan pulau yang jumlah penduduk terpadat, sehingga membutuhkan dukungan sumberdaya air yang setiap waktunya semakin meningkat. Kurang memadainya fasilitas penyaluran air di Pulau Jawa berdampak pada daya dukungnya yang semakin menurun. Hal tersebut dibuktikan dengan peristiwa banjir, tanah longsor, dan kekeringan dengan frekuensi yang semakin meningkat (Mawardi 2010). Adapun pulau lain yang memiliki kerentanan terhadap perubahan iklim. Menurut Setiawan (2012), Indonesia yang merupakan negara kepulauan yang di dalamnya terdapat pulau-pulau kecil atau pun besar menjadi sangat rentan terhadap dampak perubahan iklim. Salah satu pulau di Indonesia yang memiliki kategori pulau kecil, yaitu dengan luas kurang dari $10,000 \mathrm{~km}^{2}$, adalah Pulau Bali. Pulau Bali dengan kategori pulau kecil, menjadi sangat rentan terhadap dampak perubahan iklim.

Tujuan dari penelitian ini yaitu melakukan proyeksi kebutuhan dan ketersediaan air berdasarkan skenario perubahan iklim, mengembangkan model analisis dampak perubahan iklim terhadap sektor air berdasarkan neraca air, dan melakukan perhitungan kerugian ekonomi lingkungan yang dihasilkan akibat dari defisit air.

\section{METODOLOGI}

Wilayah yang dilakukan sebagai analisis yaitu Pulau Jawa dan Bali, terkait dengan peta wilayah tersebut disajikan pada Gambar 1. Pengolahan data sekunder dilakukan di Departemen Teknik Sipil dan lingkungan, Fakultas Teknologi Pertanian, Institut Pertanian Bogor. Waktu yang digunakan selama penelitian yaitu pada bulan AprilAgustus 2020.

Peralatan yang digunakan pada penelitian ini yaitu perangkat laptop yang dilengkapi dengan Microsoft Office dan software ArcGIS. Bahan yang digunakan yaitu data sekunder yang didapatkan dari berbagai instansi terkait, yang disajikan pada Tabel 1. Penelitian mengenai Analisis Neraca Air Pulau Jawa-Bali Sebagai Upaya Antisipasi Krisis Air dilakukan dengan delapan tahapan. Prosedur penelitian disajikan pada diagram alir yang terdapat pada Gambar 2. Terdapat perhitungan yang digunakan untuk mendapatkan besarnya nilai kebutuhan air secara keseluruhan dari sub model kebutuhan air. Perhitungan tersebut disajikan pada Persamaan (1). 


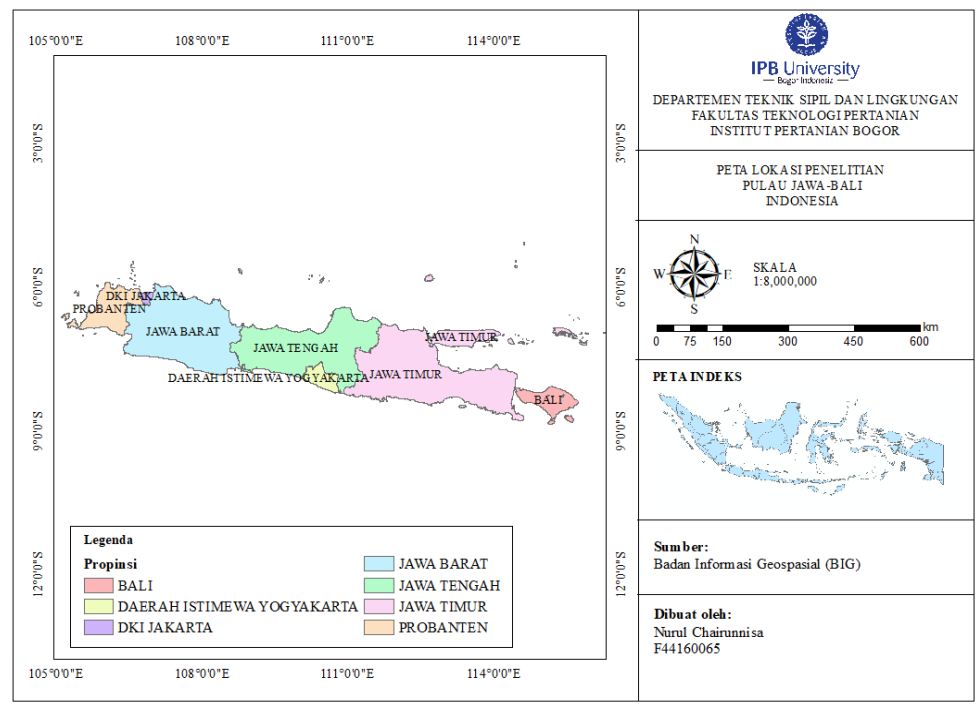

Gambar 1 Peta Lokasi Penelitian

Tabel 1 Informasi Data yang digunakan Dalam Penelitian

\begin{tabular}{lll}
\hline No & \multicolumn{1}{c}{ Jenis Data } & \multicolumn{1}{c}{ Sumber } \\
\hline 1 & Curah hujan bulanan & $\begin{array}{l}\text { Data NASA (National Aeronautics and Space } \\
\text { Administration) }\end{array}$ \\
2 & Suhu udara bulanan & $\begin{array}{l}\text { Data NASA (National Aeronautics and Space } \\
\text { Administration) }\end{array}$ \\
& & BPS (Badan Pusat Statistik) \\
3 & Data jumlah penduduk & BPS (Badan Pusat Statistik) dan Kementrian \\
4 & Data jumlah industri & Perindustrian \\
& & BPS (Badan Pusat Statistik) dan Kementerian \\
5 & Data luas sawah beririgasi dan non irigasi & Pertanian \\
& & BIG (Badan Informasi Geospasial) \\
\hline
\end{tabular}

$Q_{d}=Q_{d m}+Q_{a g r i}+Q_{i n}$

Keterangan:

$\mathrm{Q}_{\mathrm{d}} \quad=$ total kebutuhan air $\left(\mathrm{m}^{3} /\right.$ tahun $)$

$\mathrm{Q}_{\text {agri }}=$ kebutuhan air untuk pertanian ( $\mathrm{m}^{3} /$ tahun)

Q $\quad=$ kebutuhan air industri

( $\mathrm{m}^{3} /$ tahun) (Wiranta 2019)

Tahapan dalam menghitung besarnya kebutuhan air domestik didasarkan pada lokasi dengan menggunakan pendekatan standar baku mutu kebutuhan air individu per hari. Standar yang digunakan disajikan pada Tabel 2. Perhitungan mengenai kebutuhan air domestik ( $\mathrm{m}^{3} /$ tahun) disajikan pada Persamaan (2).

$$
Q_{d m}=P_{d m} \times q_{p} x t
$$

Keterangan:

$$
\begin{aligned}
\mathrm{P}_{\mathrm{dm}}= & \text { jumlah penduduk (orang) } \\
\mathrm{q}_{\mathrm{p}}= & \text { kebutuhan setiap orang } \\
& \left(\mathrm{m}^{3} /\right. \text { hari) } \\
\mathrm{t} & =\text { jumlah waktu (hari) }
\end{aligned}
$$

Kebutuhan air lainnya yang digunakan dalam analisis yaitu besarnya kebutuhan air untuk pertanian. Persamaan untuk menghitung kebutuhan air pertanian disajikan pada Persamaan (3).

$Q_{a g r i(j j)}=A_{j j} \times q_{c r o p} x t \times s$ 
Keterangan:

$\mathrm{jj} \quad=$ jenis lahan sawah (irigasi atau non irigasi)

A = luas lahan sawah $\left(\mathrm{m}^{2}\right)$

$\mathrm{q}_{\text {crop }}=$ kebutuhan air tanaman untuk setiap jenis tanaman $(\mathrm{m} /$ hari $)$

$\mathrm{t}=$ umur tanaman (hari)

$\mathrm{s}=$ sistem pola tanam
Kebutuhan rata-rata untuk tanaman padi adalah $180-300 \mathrm{~mm} /$ bulan, dan palawija adalah 100-200 mm/bulan.

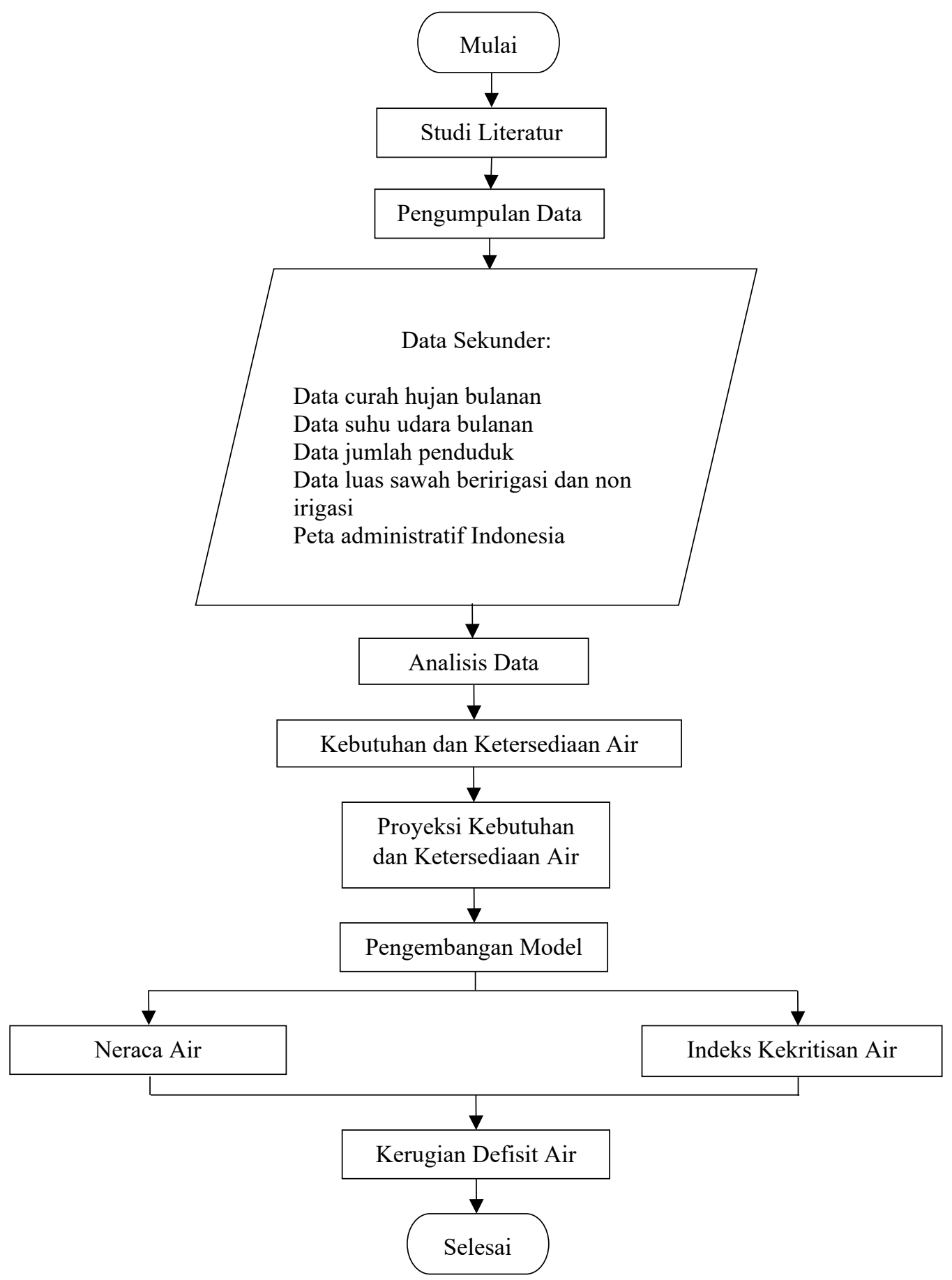

Gambar 2 Diagram Alir Penelitian 
Tabel 2 Kebutuhan Air Domestik Berdasarkan Tempat Tinggal

\begin{tabular}{lcc}
\hline \multicolumn{1}{c}{ Kategori kota } & Jumlah penduduk (jiwa) & Kebutuhan air per orang (liter/hari) \\
\hline Metropolitan & $>1.000 .000$ & $150-200$ \\
Kota besar & $500.000-1.000 .000$ & $120-150$ \\
Kota sedang & $100.000-500.000$ & $100-125$ \\
Kota kecil & $20.000-100.000$ & $90-110$ \\
Kecamatan/desa & $3.000-20.000$ & $60-90$ \\
\hline
\end{tabular}

Sumber: BSN (2015)

Selain terdapat perhitungan mengenai kebutuhan air domestik dan kebutuhan air pertanian, ada pun perhitungan mengenai kebutuhan air industri. Perhitungan mengenai kebutuhan air industri disajikan pada Persamaan (4).

$Q_{i n(j)}=P_{i n(j)} \times q_{j} \times t$

Keterangan:

$\mathrm{Q}_{\text {in }} \quad=$ jumlah kebutuhan air industri ( $\mathrm{m}^{3} /$ tahun)

$\mathrm{j} \quad=$ jenis industri

$\mathrm{P}_{\text {in }} \quad=$ jumlah industri

$\mathrm{q} \quad=$ kebutuhan air berdasarkan jenis industri $\left(\mathrm{m}^{3} /\right.$ hari)

$\mathrm{t} \quad=$ jumlah hari operasi per tahun

Analisis data dilakukan dengan menggunakan penyebab dari perubahan iklim yang dijadikan sebagai acuan utama yang dapat mempengaruhi ketersediaan air yang dapat digunakan oleh beberapa sektor. Salah satu cara yang digunakan untuk mengetahui keadaan air secara kuantitas dalam periode bulanan dalam satu tahun, yang menjelaskan air dalam kondisi surplus atau defisit air. Kedua hal tersebut sangat mempengaruhi untuk ketersediaan air yang berada pada suatu wilayah. Kondisi surplus merupakan keadaan dimana curah hujan yang jatuh pada daerah tersebut lebih besar dari pada nilai kehilangan air yang terjadi di daerah tersebut. Kondisi defisit merupakan keadaan dimana nilai kehilangan air lebih besar daripada curah hujan yang ditangkap oleh daerah tersebut. Ketersediaan air pada suatu wilayah dapat direpresentasikan dengan mengalikan nilai surplus air atau kelebihan air dengan luasan daerah tersebut, yang disajikan pada Persamaan (5).

$Q_{S}=S \times A$

Keterangan:

$\mathrm{Q}_{\mathrm{s}} \quad=$ ketersediaan air $\left(\mathrm{m}^{3} /\right.$ tahun $)$

$\mathrm{S} \quad=$ nilai kelebihan air yang bernilai positif ( $\mathrm{m} /$ tahun)

A $=$ luasan daerah $\left(\mathrm{m}^{2}\right)$

Nilai kelebihan air yang digunakan pada perhitungan pada Persamaan (5), didapatkan dengan cara perhitungan yang disajikan pada Persamaan (6).

$S=P-E P$

Keterangan:

$\mathrm{P} \quad=$ curah hujan (m/tahun) dan EP merupakan evapotranspirasi (m/tahun) (Widiyono dan Hariyanto 2016)

Nilai evapotranspirasi ditentukan menggunakan model Thornthwaite dengan digunakannya data suhu udara wilayah. Perhitungan mengenai nilai evapotranspirasi potensial digunakan beberapa persamaan yang disajikan pada Persamaan (7) sampai dengan 
Persamaan (12). Jika suhu pada wilayah kurang dari $26.5^{\circ} \mathrm{C}$ maka perhitungan evapotranspirasi yang digunakan pada Persamaan 10, sedangkan jika suhu udara lebih dari $26.5^{\circ} \mathrm{C}$ maka perhitungan evapotranspirasi yang digunakan pada Persamaan 11 (Thornthwaite 1948).

$$
\begin{aligned}
& i=\left(\frac{T}{5}\right)^{1.514} \\
& I=\sum_{J a n}^{D e s} i \\
& a=\left(0.675 \times 10^{-6} I^{3}\right)-\left(0.77 \times 10^{-4} I^{2}\right)+ \\
& 0.01792 I+0.49239 \\
& E P_{x}=16\left(10 \frac{T}{I}\right)^{a} \\
& E P_{x}=\left(-0.0433 \times t^{2}\right)+(3.224 \times t)- \\
& 41.545 \\
& E P=f E P_{x}
\end{aligned}
$$

Keterangan:

$$
\begin{aligned}
\mathrm{i} & =\text { indeks panas } \\
\mathrm{T} & =\text { suhu udara }\left({ }^{\circ} \mathrm{C}\right) \\
\mathrm{I} & =\text { jumlah indeks panas dalam } \\
& \text { waktu satu tahun } \\
\mathrm{EPx} \quad= & \text { evapotranspirasi potensial } \\
& \text { sebelum terkoreksi (mm/bulan) } \\
\mathrm{EP} \quad= & \text { evapotranspirasi potensial } \\
& \text { terkoreksi (mm/bulan) } \\
\mathrm{f} \quad= & \text { faktor koreksi }
\end{aligned}
$$

Besarnya nilai surplus atau defisit air ditentukan dengan menggunakan beberapa perhitungan, diantaranya yaitu APWL (akumulasi potensi kehilangan air) dalam satuan $\mathrm{mm} /$ bulan yang digunakan untuk mengetahui kehilangan air pada saat bulan kering. APWL akan bernilai 0 ketika bulan basah, sedangkan APWL pada bulan kering dihitung dengan menggunakan rumus yang disajikan pada Persamaan (13).

$A P W L=A P W L_{(t-1)}-S_{(t)}$

Nilai cadangan lengas tanah diperhitungkan sebagai tahapan dalam mendapatkan besarnya nilai surplus dan defisit air pada wilayah dan waktu tertentu. Nilai cadangan lengas tanah didapatkan dengan mengalikan antara persentase luas penggunaan lahan, air yang tersedia dan kedalaman zona perakaran. Rumus yang digunakan dalam menghitung cadangan lengas tanah disajikan pada Persamaan (14) dan Persamaan (15), sedangkan untuk perhitungan perubahan cadangan lengas tanah dalam selang waktu per tahun disajikan pada Persamaan (16).

$$
\begin{aligned}
& S T_{0}=\frac{S T \text { per lahan }}{\sum A_{z p} \text { per lahan }} \\
& S T=S T_{0} \times e^{\left(-\left(\frac{A P W L}{S T_{0}}\right)\right)} \\
& \Delta S T=S T_{0}-S T
\end{aligned}
$$

Keterangan:

ST = cadangan lengas tanah $(\mathrm{mm})$

$\Sigma \mathrm{A}_{\mathrm{zp}} \quad=$ persentase luas zona perakaran per penggunaan lahan

$\Delta \mathrm{ST}=$ perubahan cadangan lengas tanah dalam selisih per tahun (mm)

Setelah melakukan perhitungan mengenai cadangan lengas tanah, maka dilakukan perhitungan mengenai evapotranspirasi aktual (EA) (mm/bulan). Ketika bulan basah maka nilai evapotranspirasi aktual sama dengan nilai evapotranspirasi potensial terkoreksi. Namun ketika terjadi bulan kering, maka nilai evapotranspirasi aktual dihitung dengan menggunakan perhitungan yang disajikan pada Persamaan (17).

$E A=P+\Delta S T$ 
Nilai neraca air dapat diketahui berdasarkan nilai surplus dan defisit pada suatu wilayah per tahun, yang dilihat berdasarkan kondisi bulan basah dan bulan kering. Besarnya nilai surplus air (S) dalam satuan mm/bulan dapat dihitung dengan rumus yang terdapat pada Persamaan (18). Perhitungan tersebut dilakukan ketika terjadi bulan basah, sedangkan pada saat terjadi bulan kering nilai surplus air bernilai 0 . Defisit air (D) dalam satuan $\mathrm{mm} /$ bulan dihitung dengan rumus yang disajikan pada Persamaan (19) dengan kondisi pada bulan kering, sedangkan pada bulan basah nilai defisit air yaitu 0 .

$S=(P-E P)-\Delta S T$

$D=E P-E A$

Setelah mendapatkan nilai surplus dan defisit, maka dihitung besarnya persentase dari surplus dan defisit tersebut. Persentase ketika kondisi surplus dihitung dengan rumus yang disajikan pada Persamaan (20), sedangkan pada kondisi defisit dihitung dengan menggunakan rumus pada Persamaan (21).

$\% S=\frac{S}{(S+D)} \times 100 \%$
$\% D=\frac{D}{(S+D)} \times 100 \%$

Menurut Wijayanti et al. (2015), perbandingan antara ketersediaan air dengan kebutuhan air disebut sebagai indeks kekritisan air (IKA). Nilai ketersediaan dan kebutuhan air yang dimiliki oleh suatu wilayah dapat digunakan untuk mengkaji terkait dengan air yang tersedia pada suatu wilayah. Adapun perhitungan yang menjelaskan mengenai IKA disajikan pada Persamaan (22). Berdasarkan perhitungan tersebut, diperoleh nilai IKA yang dapat dikategorikan berdasarkan kelas kondisi air yang disajikan pada Tabel 3 .

$I K A=\frac{Q_{d}}{Q_{s}} \times 100 \%$

Tabel 3 Klasifikasi Nilai Indeks

Kekritisan Air (IKA)

\begin{tabular}{ccc}
\hline No & $\begin{array}{c}\text { Indeks Kekritisan } \\
(\%)\end{array}$ & Kelas \\
\hline 1 & $<50$ & Belum kritis \\
2 & $50-75$ & Mendekati kritis \\
3 & $75-100$ & Kritis \\
4 & $>100$ & Sangat kritis \\
\hline
\end{tabular}

Sumber: Bina Program Pengairan (2005)

Berdasarkan skenario perubahan iklim berupa kenaikan rata-rata suhu udara sebesar $1^{\circ} \mathrm{C}$, akan meningkatkan evapotranspirasi potensial yang berindikasi akan menurunkan ketersediaan air dan meningkatkan kebutuhan air. Faktor utama yang berpengaruh terhadap perubahan ketersediaan dan kebutuhan air yaitu jumlah dan pola penyebaran penduduk (Redjekiningrum 2011). Proyeksi pertumbuhan penduduk dapat dilakukan dengan tiga metode, yaitu metode aritmatika, metode geometrik, dan metode eksponensial. Berdasarkan ketiga metode tersebut, untuk menentukan metode yang tepat untuk melakukan proyeksi yaitu yang memiliki standar deviasi terkecil. Ada pula faktor lain yang dipertimbangkan, yaitu nilai koefisien korelasi. Metode yang memiliki nilai koefisien korelasi mendekati 1 merupakan metode yang tepat dan dipilih (Widayani 2016). Rumus yang digunakan pada metode artimatika, geometrik, dan eksponensial beserta rumus nilai laju pertumbuhan pada masing-masing metode disajikan pada Persamaan (23) sampai dengan Persamaan (28). 


$$
\begin{aligned}
& P t=P o \times(1+r t) \\
& r=\frac{1}{t} \times\left(\frac{P t}{P o}-1\right) \ldots \\
& P t=P o \times(1+r)^{t} \\
& r=\left(\frac{P t}{P o}\right)^{\frac{1}{t}}-1 \ldots \ldots . \\
& P t=P o \times E^{r t} \ldots \ldots \\
& r=\frac{1}{t} \times \ln \left(\frac{P t}{P o}\right) \ldots \ldots
\end{aligned}
$$

Keterangan:

$$
\begin{aligned}
\mathrm{P}(\mathrm{t}) \quad= & \text { jumlah penduduk pada tahun } \\
& \text { ke- } \mathrm{t} \text { (orang) } \\
\mathrm{P}_{\mathrm{o}} \quad & \text { jumlah penduduk pada tahun } \\
& \text { awal proyeksi (orang) } \\
\text { nilai } 1= & \text { angka konstanta } \\
\mathrm{r} \quad & \text { angka pertumbuhan penduduk } \\
& \text { (dalam persen) } \\
\mathrm{n} \quad & \text { jumlah rentang tahun dari awal } \\
& \text { hingga tahun } \mathrm{n}
\end{aligned}
$$

Analisis ekonomi lingkungan dilakukan dengan cara mengetahui kondisi defisit ketersediaan air dalam rentang per tahun dan dengan cara mengetahui kerugian dalam rupiah yang diakibatkan oleh berkurangnya kondisi air. Besarnya kerugian defisit ketersediaan air dapat diketahui dengan menggunakan harga dasar air yang ditentukan pada Kepmen PUPR No. 12/KPTS/M/2019. Perhitungan mengenai defisit ketersediaan air disajikan pada Persamaan (29), dan kerugian defisit ketersediaan air dalam rupiah disajikan pada Persamaan (30).

$$
\begin{aligned}
& D e f_{(t)}=Q s_{(t-1)}-Q s_{(t)} \\
& W_{L}=\text { Def } \times H D A \ldots \ldots
\end{aligned}
$$

Keterangan:

Def $=$ defisit ketersediaan air

$$
\begin{aligned}
& \left(\mathrm{m}^{3} / \text { tahun }\right) \\
\mathrm{t}= & \text { tahun perhitungan defisit } \\
& \text { ketersediaan air } \\
\mathrm{WL}= & \text { kerugian defisit air }(\mathrm{Rp}) \\
\mathrm{HDA}= & \text { adalah harga dasar air }\left(\mathrm{Rp} / \mathrm{m}^{3}\right)
\end{aligned}
$$

\section{HASIL DAN PEMBAHASAN}

\section{Kebutuhan Air}

Terdapat tiga jenis kebutuhan air yang digunakan pada perhitungan, diantaranya yaitu kebutuhan air domestik, kebutuhan air pertanian dan kebutuhan air industri. Kebutuhan air di masa mendatang sangat berpengaruh terhadap keberlangsungan makhluk hidup di muka bumi ini. Maka perlu dilakukan proyeksi yang bertujuan untuk mengetahui kebutuhan air di masa mendatang yang dipengaruhi oleh beberapa faktor. Proyeksi yang dilakukan terhitung dalam rentang waktu 30 tahun, dengan data utama pada tahun 1991 sampai dengan 2020 dan data proyeksi pada tahun 2021 sampai dengan 2050 .

\section{Kebutuhan Air Domestik}

Faktor utama yang dijadikan penentu sebagai perhitungan kebutuhan air domestik yaitu jumlah pertumbuhan penduduk dalam setiap tahun. Cara untuk mengetahui pertumbuhan jumlah penduduk dalam jangka waktu kedepan yaitu dengan cara melakukan proyeksi penduduk. Terdapat tiga jenis metode proyeksi penduduk, yaitu metode aritmatika, geometrik dan eksponensial. Berdasarkan ketiga metode tersebut, untuk menentukan metode yang tepat untuk melakukan proyeksi yaitu yang memiliki standar deviasi terkecil. Ada pula faktor lain yang dipertimbangkan, yaitu nilai koefisien korelasi. Metode yang memiliki nilai koefisien korelasi mendekati satu merupakan metode yang tepat dan dipilih (Widayani 2016). Hasil 
dari perhitungan menunjukkan satu metode yang memiliki kriteria dengan koefisien korelasi yang mendekati satu dan standar deviasi yang terkecil diantara ketiga metode tersebut. Metode yang dipilih yaitu metode eksponensial.

Faktor lain yang terlibat dalam perhitungan kebutuhan air domestik yaitu kebutuhan air domestik berdasarkan kategori tempat tinggal, yaitu sebesar $200 \mathrm{~L} /$ orang/hari atau 0.2 $\mathrm{m}^{3}$ /orang/hari, dan banyaknya hari yang digunakan dalam perhitungan yaitu 365 hari.

Rata-rata jumlah penduduk di Pulau Jawa pada tahun 1991 sampai dengan 2020 yaitu sebanyak 132.12 juta jiwa, dengan kebutuhan air domestik sebesar 9.64 miliar $\mathrm{m}^{3}$. Provinsi di Pulau Jawa yang memiliki rata-rata jumlah penduduk tertinggi yaitu Provinsi Jawa Barat, sebanyak 42.78 juta jiwa dengan kebutuhan air domestik sebesar 3.12 miliar $\mathrm{m}^{3}$, sedangkan daerah yang memiliki rata-rata jumlah penduduk terendah yaitu Provinsi DI Yogyakarta sebanyak 3.38 juta jiwa, dengan kebutuhan air domestik sebesar 0.25 miliar $\mathrm{m}^{3}$. Pulau Bali dalam rentang tahun tersebut memiliki rata-rata jumlah penduduk sebanyak 3.39 juta jiwa, dengan kebutuhan air domestik sebesar 0.25 miliar $\mathrm{m}^{3}$.

Seiring berjalannya waktu, jumlah penduduk dan kebutuhan air domestik pada setiap wilayah mengalami peningkatan. Tahun 2021 sampai dengan 2050 Pulau Jawa memiliki rata-rata jumlah penduduk sebanyak 193.82 juta jiwa, dengan kebutuhan air domestik sebesar 14.15 miliar $\mathrm{m}^{3}$. Provinsi Jawa Timur merupakan daerah yang memiliki rata-rata jumlah penduduk tertinggi pada rentang waktu tersebut, yaitu sebanyak 61.92 juta jiwa dengan kebutuhan air domestik sebesar 4.52 miliar $\mathrm{m} 3$, sedangkan rata-rata jumlah penduduk terendah berada di Provinsi DI
Yogyakarta sebanyak 4.39 juta jiwa, dengan kebutuhan air domestik sebesar 0.32 miliar m3. Pulau Bali dalam rentang waktu tersebut memiliki rata-rata jumlah penduduk sebanyak 6.02 juta jiwa, dengan kebutuhan air domestik sebesar 0.44 miliar $\mathrm{m}^{3}$.

\section{Kebutuhan Air Pertanian}

Terdapat dua jenis lahan pertanian berdasarkan sumber pengairannya, yaitu luas lahan sawah irigasi dan luas lahan sawah non irigasi. Diasumsikan jenis lahan sawah irigasi menggunakan sistem pola tanam padi-padi-padi, dan sedangkan untuk jenis lahan sawah non irigasi menggunakan sistem pola tanam padi-palawija. Sistem pola tanam yang diterapkan selama satu tahun, atau terhitung sebanyak 365 hari. Usia tanaman padi pada satu kali tanam yaitu 110 hari, sedangkan untuk palawija selama 120 hari. Besarnya kebutuhan air tanaman yang diperlukan untuk padi sebesar 180 sampai dengan 330 $\mathrm{mm} /$ bulan, yang digunakan pada perhitungan yaitu sebesar 220 $\mathrm{mm} /$ bulan. Adapun besarnya kebutuhan air tanaman pada palawija sebesar 100 sampai dengan $200 \mathrm{~mm} /$ bulan, namun yang digunakan pada perhitungan yaitu sebesar $150 \mathrm{~mm} /$ bulan.

Berdasarkan hasil perhitungan, rata-rata luas lahan pertanian di Pulau Jawa pada tahun 1991 sampai dengan 2020 sebesar 32.29 miliar $\mathrm{m}^{2}$, dengan kebutuhan air pertanian sebesar 69.65 miliar $\mathrm{m}^{3}$. Provinsi di Pulau Jawa yang memiliki rata-rata luas lahan pertanian terbesar yaitu Provinsi Jawa Timur sebesar 11.04 miliar $\mathrm{m}^{2}$, dengan kebutuhan air pertanian sebesar 24.03 miliar $\mathrm{m}^{3}$, sedangkan daerah yang memiliki rata-rata luas lahan pertanian terendah yaitu Provinsi DKI Jakarta yaitu sebesar 0.01 miliar $\mathrm{m}^{2}$, dengan kebutuhan air pertanian sebesar 0.03 miliar $\mathrm{m}^{3}$. Pulau Bali dalam rentang 
waktu tersebut memiliki rata-rata luas lahan pertanian sebesar 0.80 miliar $\mathrm{m}^{2}$, dengan kebutuhan air pertanian sebesar 1.09 miliar $\mathrm{m}^{3}$.

Pada tahun 2021 sampai dengan 2050 Pulau Jawa memiliki rata-rata luas lahan pertanian sebesar 33.75 miliar $\mathrm{m}^{2}$, dengan kebutuhan air sebesar 72.35 miliar $\mathrm{m}^{3}$. Daerah di Pulau Jawa pada rentang waktu tersebut yang memiliki rata-rata luas lahan pertanian terbesar yaitu Provinsi Jawa Tengah sebesar 11.33 miliar $\mathrm{m}^{2}$, dengan kebutuhan air pertanian sebesar 24.26 miliar $\mathrm{m}^{3}$. Daerah yang memiliki rata-rata luas lahan pertanian terendah yaitu Provinsi DKI Jakarta dengan rata-rata luas lahan pertanian sebesar 0.01 miliar $^{2}$, dengan kebutuhan air pertanian sebesar 0.01 miliar $\mathrm{m}^{3}$. Pulau Bali dalam rentang waktu tersebut memiliki rata-rata luas lahan pertanian sebesar 0.74 miliar $\mathrm{m}^{2}$, dengan kebutuhan air pertanian sebesar 1.76 miliar $\mathrm{m}^{3}$.

\section{Kebutuhan Air Industri}

Jenis industri di Indonesia dibagi menjadi empat jenis, yaitu industri rumah tangga, industri kecil, industri sedang, dan industri besar. Masingmasing jenis industri memiliki kapasitas jumlah tenaga kerja dan kebutuhan air industri yang berbeda. Parameter yang digunakan dalam perhitungan besarnya kebutuhan air industri yaitu kebutuhan air industri berdasarkan jenis industri, jumlah hari kerja industri dalam satu tahun. Menurut Kumalajati et al. (2015), banyaknya hari kerja untuk industri diasumsikan 22 hari libur nasional dan 48 hari libur mingguan, maka total hari kerja yang digunakan sebanyak 296 hari dalam satu tahun. Perhitungan menghasilkan jumlah industri dari berbagai jenis dalam setiap provinsi. Besarnya nilai kebutuhan air industri dihitung berdasarkan jenis industri lalu dijumlahkan dalam rentang waktu satu tahun per daerah.

Rata-rata jumlah industri pada tahun 1991 sampai dengan 2020 di Pulau Jawa sebanyak 1.9 juta unit, dengan kebutuhan air industri sebesar 115.31 juta $\mathrm{m}^{3}$. Daerah yang memiliki rata-rata jumlah industri tertinggi yaitu Jawa Tengah sebanyak 732.52 ribu unit, dengan kebutuhan air industri sebesar 42.17 juta $\mathrm{m}^{3}$. Sedangkan untuk daerah yang memiliki rata-rata jumlah industri terendah yaitu Provinsi DKI Jakarta sebanyak 35.47 ribu unit. Namun pada rentang waktu tersebut untuk wilayah Pulau Jawa, yang memiliki kebutuhan air industri terendah yaitu Provinsi Banten sebesar 3.29 juta $\mathrm{m}^{3}$. Hal tersebut dapat terjadi karena jumlah industri pada setiap wilayah berdasarkan jenis industri berbeda-beda, maka besarnya faktor pengali dalam perhitungan kebutuhan air industri pun berbeda. Pulau Bali memiliki rata-rata jumlah industri sebanyak 94.90 ribu unit, dengan kebutuhan air industri sebesar 5.03 juta $\mathrm{m}^{3}$.

Berdasarkan hasil proyeksi, ratarata jumlah industri dan kebutuhan air industri semakin bertambah. Pada tahun 2021 sampai dengan 2050, rata-rata jumlah industri di Pulau Jawa sebanyak 2.6 juta unit dengan kebutuhan air industri sebesar 153.31 juta $\mathrm{m}^{3}$. Daerah di Pulau Jawa yang memiliki rata-rata jumlah industri tertinggi yaitu Provinsi yaitu Jawa Tengah sebanyak 946.72 ribu unit. Namun pada rentang waktu tersebut, daerah yang memiliki kebutuhan air industri tertinggi yaitu Provinsi Jawa Timur sebesar 52.71 juta $\mathrm{m}^{3}$. Daerah yang memiliki rata-rata jumlah industri terendah yaitu Provinsi DKI Jakarta sebanyak 46 ribu unit, dengan kebutuhan air industri sebesar 4.30 juta $\mathrm{m}^{3}$. Pulau Bali dalam rentang waktu tersebut memiliki rata-rata jumlah industri sebanyak 126.92 ribu unit, 
dengan kebutuhan air industri sebesar 6.22 juta $\mathrm{m}^{3}$.

\section{Kebutuhan Air Total}

Kebutuhan air total merupakan penjumlahan dari kebutuhan air sektor domestik, pertanian, dan industri. Kebutuhan air total dirata-ratakan dalam rentang tahun 1991 sampai dengan 2020 dan tahun 2020 sampai dengan 2050. Rata-rata kebutuhan air total di Pulau Jawa pada tahun 1991 sampai dengan 2020 yaitu sebesar 79.41 miliar $\mathrm{m}^{3}$, dengan Provinsi Jawa Timur sebagai daerah yang memiliki kebutuhan air tertinggi yaitu sebesar 26.82 miliar $\mathrm{m}^{3}$ dan DKI Jakarta sebagai provinsi yang memiliki kebutuhan air terendah yaitu sebesar 0.67 miliar $\mathrm{m}^{3}$. Pulau Bali dalam rentang waktu tersebut memiliki ratarata kebutuhan air total sebesar 2.15 miliar m3. Rata-rata kebutuhan air hasil proyeksi mengalami peningkatan dibandingkan dengan waktu sebelumnya. Wilayah Pulau Jawa dalam renang tahun 2021 sampai dengan 2050 memiliki rata-rata kebutuhan air total sebesar 86.65 miliar $\mathrm{m}^{3}$, dengan rata-rata kebutuhan air total tertinggi berada di Provinsi Jawa Timur yaitu sebesar 27.87 miliar $\mathrm{m}^{3}$, dan rata-rata kebutuhan air terendah yaitu pada Provinsi DKI Jakarta sebesar 1.01 miliar $\mathrm{m}^{3}$. Pulau Bali dalam rentang waktu tersebut memiliki ratarata kebutuhan air total sebesar 2.21 miliar $\mathrm{m}^{3}$.

\section{Iklim}

Faktor iklim yang dijadikan sebagai acuan diantaranya yaitu curah hujan dan suhu udara. Terdapat jenis skenario perubahan iklim yaitu RCP (Representative Carbon Pathway). Terdapat beberapa jenis RCP, diantaranya yaitu RCP 2.6, 4.5, 6.0, dan 8.5. Namun yang digunakan dalam penelitian ini yaitu RCP 4.5, dengan model GCM (Global Climate Model) yaitu CSIRO (Commonwealth Scientific and Industrial Research Organization) dan MIROC (Model for Interdisciplinary Research on Climate). RCP 4.5 banyak digunakan pada pemodelan proyeksi iklim yang berfungsi untuk menentukan kondisi iklim dalam jangka waktu ke depan, yang dikarenakan adanya radiative forcing yang mencapai $4.5 \mathrm{watt} / \mathrm{m}^{2}$ yang disebabkan oleh senyawa gas rumah kaca, sehingga terjadi peningkatan suhu (Nurlatifah et al. 2018).

\section{Curah Hujan}

Wilayah yang digunakan dalam penelitian ini merupakan wilayah Pulau Jawa dan Pulau Bali yang termasuk ke dalam daerah yang didominasi oleh curah hujan pola monsunal. Menurut Hermawan (2010), ciri yang dimiliki oleh pola hujan monsunal yaitu tipe curah hujan yang memiliki satu puncak musim hujan (unimodial). Pembagian bulan kering terjadi pada bulan Juni, Juli, dan Agustus (JJA), sedangkan bulan basah terjadi pada bulan Desember, Januari, dan Februari (DJF). Bulan yang tidak terdapat di dalam bulan basah dan bulan kering merupakan periode peralihan atau biasa disebut sebagai pancaroba, yang dimana tiga bulan peralihan musim kemarau ke musim hujan dan tiga bulan peralihan musim hujan ke musim kemarau.

Berdasarkan data curah hujan, curah hujan tertinggi pada periode pertama di wilayah Pulau Jawa dengan model CSIRO dan MIROC terdapat pada Provinsi Jawa Tengah yaitu sebesar $2,756.86 \mathrm{~mm}$ dan 2,648.65 $\mathrm{mm}$, sedangkan untuk curah hujan terendah dimiliki oleh Provinsi Jawa Timur yaitu sebesar 2,155.52 $\mathrm{mm}$ dan 2,074.45 $\mathrm{mm}$ dalam rentang waktu 30 tahun. Pulau Bali memiliki curah hujan pada periode tersebut dengan model CSIRO dan 
MIROC yaitu sebesar 2,070.92 $\mathrm{mm}$ dan $1,945.17 \mathrm{~mm}$ dalam rentang 30 tahun. Tidak berbeda halnya periode kedua atau pada tahun 2021 sampai degan 2050 dengan model CSIRO dan MIROC di Pulau Jawa secara berturut-turut wilayah yang memiliki curah hujan tertinggi yaitu Provinsi Jawa Tengah sebesar $2,618 \mathrm{~mm}$ dan $2,712.18 \mathrm{~mm}$, sedangkan untuk wilayah yang memiliki curah hujan terendah pada periode tersebut yaitu Provinsi Jawa Timur dengan model CSIRO dan MIROC berturut-turut sebesar 2,029.06 mm dan 2,148.06 mm. Pulau Bali dalam rentang waktu tersebut memiliki nilai curah hujan dengan model CSIRO dan MIROC secara berturutturut yaitu $1,808.49 \mathrm{~mm}$ dan $2,172.62$ $\mathrm{mm}$.

\section{Suhu Udara dan Evapotranspirasi}

Metode yang digunakan dalam menghitung besarnya evapotranspirasi wilayah dengan menggunakan salah satunya faktor suhu udara pada suatu wilayah yaitu metode Thornthwaite. Faktor lain yang digunakan yaitu indeks panas dan nilai koreksi yang disesuaikan berdasarkan letak titik koordinat wilayah. Sehingga hasil pengolahan data mengenai evapotranspirasi digunakan untuk menghitung besarnya nilai kelebihan air yang disertai dengan nilai curah hujan wilayah.

Model CSIRO pada wilayah Pulau Jawa pada tahun 1991 sampai dengan 2020 memiliki nilai evapotranspirasi tertinggi pada bulan Oktober yaitu sebesar $146.91 \quad \mathrm{~mm}$, dan evapotranspirasi terendah yaitu pada bulan Februari sebesar $123.08 \mathrm{~mm}$. Selain Pulau Jawa, ada pun Pulau Bali yang memiliki evapotranspirasi tertinggi terjadi pada bulan Oktober yaitu sebesar $158.50 \mathrm{~mm}$ dan evapotranspirasi terendah pada bulan Juli yaitu sebesar $123.05 \mathrm{~mm}$. Sedangkan pada tahun 2021 sampai dengan 2050 Pulau Jawa memiliki evapotranspirasi tertinggi pada bulan Oktober yaitu sebesar $150.69 \mathrm{~mm}$ dan terendah pada bulan Februari sebesar $128.63 \mathrm{~mm}$. Pulau Bali dalam rentang waktu tersebut memiliki nilai evapotranspirasi tertinggi pada bulan Oktober sebesar $164.73 \mathrm{~mm}$ dan terendah pada bulan Juli sebesar 136.22 $\mathrm{mm}$.

Tidak berbeda halnya dengan model MIROC, dalam rentang tahun 1991 sampai dengan 2020 pada Pulau Jawa nilai evapotranspirasi tertinggi terjadi pada bulan Oktober yaitu sebesar $145.83 \mathrm{~mm}$, dan yang terendah terjadi pada bulan Februari yaitu sebesar 125.36 $\mathrm{mm}$. Pulau Bali pada model dan rentang waktu tersebut memiliki nilai evapotranspirasi tertinggi pada bulan Oktober yaitu sebesar $156.75 \mathrm{~mm}$, dan terendah pada bulan Juli yaitu sebesar $125.05 \mathrm{~mm}$. Sedangkan pada tahun 2021 sampai dengan 2050 Pulau Jawa memiliki evapotranspirasi tertinggi pada bulan Oktober yaitu sebesar $151.72 \mathrm{~mm}$ dan terendah pada bulan Februari sebesar $129.35 \mathrm{~mm}$. Pulau Bali dalam rentang waktu tersebut memiliki nilai evapotranspirasi tertinggi pada bulan Oktober sebesar $162.19 \mathrm{~mm}$ dan terendah pada bulan Februari sebesar $135.85 \mathrm{~mm}$.

\section{Ketersediaan Air}

Terdapat dua jenis ketersediaan air wilayah, yang dinilai berdasarkan model CSIRO dan MIROC. Curah hujan yang digunakan sebagai perhitungan yaitu curah hujan per bulan. Ketika terjadi bulan basah atau musim hujan, maka ketersediaan air meningkat, sedangkan pada periode bulan kering maka terjadi hal yang sebaliknya.

Berdasarkan hasil perhitungan mengenai ketersediaan air dengan model CSIRO, pada tahun 1991 sampai dengan 2020 untuk wilayah Pulau Jawa 
memiliki rata-rata ketersediaan air sebesar 620.19 miliar $\mathrm{m}^{3}$, dengan Provinsi Jawa Tengah yang memiliki rata-rata ketersediaan air tertinggi yaitu sebesar 509.41 miliar $\mathrm{m}^{3}$, sedangkan untuk daerah yang memilki ketersediaan air terendah yaitu DKI Jakarta sebesar 0.52 miliar $\mathrm{m}^{3}$. Pulau Bali dalam rentang waktu tersebut memiliki ketersediaan air sebesar 5.22 miliar $\mathrm{m}^{3}$. Hasil proyeksi pada tahun 2021 sampai dengan 2050 mengalami penurunan ketersediaan air pada setiap wilayah di Pulau Jawa terkecuali Provinsi Banten. Pulau Jawa dalam rentang waktu tersebut memiliki rata-rata ketersediaan air sebesar 544.51 miliar $\mathrm{m}^{3}$, dengan daerah yang memiliki rata-rata kebutuhan air tertinggi yaitu Provinsi Jawa Tengah sebesar 448.08 miliar $\mathrm{m}^{3}$, dan daerah yang memiliki rata-rata kebutuhan air terendah yaitu Provinsi DKI Jakarta sebesar 0.51 miliar $\mathrm{m}^{3}$. Pulau Bali dalam rentang waktu tersebut memiliki rata-rata kebutuhan air sebesar 4.03 miliar $\mathrm{m}^{3}$.

Model lain yang digunakan yaitu MIROC, model tersebut menghasilkan nilai rata-rata ketersediaan air yang berbeda dengan model sebelumnya. Rata-rata ketersediaan air pada tahun 1991 sampai dengan 2020 untuk wilayah Pulau Jawa sebesar 548.18 miliar $\mathrm{m}^{3}$, dengan daerah yang memiliki rata-rata ketersediaan air tertinggi yaitu Provinsi Jawa Tengah sebesar 456.45 miliar $\mathrm{m}^{3}$, dan daerah yang memiliki rata-rata ketersediaan air terendah yaitu Provinsi DKI Jakarta sebesar 0.42 miliar $\mathrm{m}^{3}$. Pulau Bali dalam rentang tahun tersebut memiliki rata-rata ketersediaan air sebesar 3.83 miliar $\mathrm{m}^{3}$. Tahun 2021 sampai dengan 2050 memiliki nilai rata- rata ketersediaan air yang berbeda. Pulau Jawa dalam rentang waktu tersebut memiliki rata-rata ketersediaan air sebesar 566.69 miliar $\mathrm{m}^{3}$, dengan daerah yang memiliki rata-rata kebutuhan air tertinggi yaitu Provinsi Jawa Tengah sebesar 470.55 miliar $\mathrm{m}^{3}$, dan daerah yang memiliki rata-rata kebutuhan air terendah yaitu Provinsi DKI Jakarta sebesar 0.48 miliar $\mathrm{m}^{3}$. Pulau Bali dalam rentang waktu tersebut memiliki ratarata kebutuhan air sebesar 4.50 miliar $\mathrm{m}^{3}$.

\section{Neraca Air}

Menurut Widiyono dan Hariyanto (2016), curah hujan yang jatuh di permukaan bumi berhubungan dengan keseimbangan air atau neraca air. Neraca air merupakan neraca masukan dan keluarnya air di suatu wilayah pada periode tertentu. Hal tersebut maka dapat digunakan untuk mengetahui jumlah surplus (kelebihan) dan defisit (kekurangan) air. Neraca air yang dihasilkan merupakan neraca air lahan yang dihitung berdasarkan kondisi bulan basah dan bulan kering. Ketika bulan basah terjadi maka kondisi air terjadi surplus, sedangkan jika terjadi bulan kering maka kondisi air defisit.

Hasil perhitungan menunjukkan bahwa umumnya surplus air terbesar dibandingkan dengan defisit terjadi pada bulan Oktober sampai dengan April. Ketika defisit nilainya lebih besar daripada surplus, hal tersebut umumnya terjadi pada bulan Mei sampai dengan September. 
Tabel 4 Data Neraca Air Model CSIRO Pulau Jawa dan Bali Tahun 1991-2050

\begin{tabular}{lcccc}
\hline \multirow{2}{*}{ Provinsi } & \multicolumn{2}{c}{$1991-2020$} & \multicolumn{2}{c}{ 2021-2050 } \\
\cline { 2 - 5 } & Surplus (\%) & Defisit (\%) & Surplus (\%) & Defisit (\%) \\
\hline DKI Jakarta & 64.98 & 35.02 & 60.71 & 39.29 \\
Jawa Barat & 89.57 & 10.43 & 85.23 & 14.77 \\
Jawa Tengah & 87.26 & 12.74 & 81.88 & 18.12 \\
Jawa Timur & 68.34 & 31.66 & 60.35 & 39.65 \\
DI Yogyakarta & 74.25 & 25.75 & 65.66 & 34.34 \\
Banten & 82.74 & 17.26 & 77.06 & 22.94 \\
Bali & 64.68 & 35.32 & 51.79 & 48.21 \\
\hline
\end{tabular}

Berdasarkan Tabel 4, daerah di Pulau Jawa yang memiliki surplus tertinggi pada tahun 1991 sampai dengan 2020 yaitu Provinsi Jawa Barat sebesar $89.57 \%$ dan daerah yang memiliki surplus terendah yaitu Provinsi DKI Jakarta yaitu $64.98 \%$. Pulau Bali dalam rentang tahun tersebut memiliki nilai surplus air sebesar $64.68 \%$. Tidak berbeda halnya pada tahun 2021 sampai dengan 2050, daerah yang memiliki surplus air tertinggi di Pulau Jawa yaitu Provinsi Jawa Barat sebesar 85.23\%, dan daerah yang memiliki surplus air terendah yaitu Provinsi Jawa Timur sebesar 60.35\%. Pulau Bali dalam rentang waktu tersebut memiliki nilai surplus air sebesar $51.79 \%$. Ada pun model lainnya yang digunakan pada analisis neraca air, yaitu model MIROC. Hasil dari perhitungan neraca air dengan model MIROC disajikan pada Tabel 5.

Tabel 5 Data Neraca Air Model MIROC Pulau Jawa dan Bali Tahun 1991-2050

\begin{tabular}{lcccc}
\hline \multirow{2}{*}{ Provinsi } & \multicolumn{2}{c}{$1991-2020$} & \multicolumn{2}{c}{ 2021-2050 } \\
\cline { 2 - 5 } & Surplus & Defisit & Surplus & Defisit \\
\hline DKI Jakarta & 65.00 & 35.00 & 62.39 & 37.61 \\
Jawa Barat & 91.58 & 8.42 & 88.49 & 11.51 \\
Jawa Tengah & 88.55 & 11.45 & 85.11 & 14.89 \\
Jawa Timur & 66.98 & 33.02 & 66.00 & 34.00 \\
DI Yogyakarta & 74.31 & 25.69 & 72.20 & 27.80 \\
Banten & 87.74 & 12.26 & 84.72 & 15.28 \\
Bali & 62.79 & 37.21 & 66.17 & 33.83 \\
\hline
\end{tabular}

Berdasarkan data neraca air model MIROC yang terlampir di Tabel 5, dijelaskan bahwa nilai surplus pada masing-masing provinsi berbeda. Provinsi di Pulau Jawa pada tahun 1991 sampai dengan 2020 yang memiliki nilai surplus tertinggi berada di Provinsi Jawa Barat yaitu sebesar $91.58 \%$, sedangkan untuk provinsi yang memiliki nilai surplus terendah yaitu Provinsi DKI Jakarta sebesar $65 \%$. Pulau Bali dalam rentang waktu tersebut memiliki nilai surplus sebesar $62.79 \%$. Wilayah Pulau Jawa berdasarkan data diatas, semakin berjalannya waktu mengalami penurunan nilai surplus air, namun tidak terjadi pada Pulau Bali. Data surplus air pada tahun 2021 sampai dengan 2050 untuk Pulau Jawa yang memiliki nilai surplus tertinggi yaitu Provinsi Jawa Barat sebesar $88.49 \%$, sedangkan provinsi yang memiliki nilai surplus terendah yaitu DKI Jakarta sebesar $62.39 \%$. Pulau Bali dalam rentang waktu tersebut memiliki nilai surplus sebesar $66.17 \%$. 


\section{Indeks Kekritisan Air}

Indeks kekritisan air dipengaruhi oleh kebutuhan air dan ketersediaan air pada suatu wilayah. Status indeks kekritisan air pada masing-masing provinsi yang berada di Pulau Jawa berbeda. Penilaian indeks kekritisan air dilakukan dalam waktu 60 tahun yang dibagi ke dalam dua periode, periode pertama dalam rentang tahun 1991 sampai dengan 2020 dan periode kedua pada tahun 2021 sampai dengan 2050, dengan penggunaan dua model yaitu model CSIRO dan MIROC.

Perubahan nilai indeks kekritisan air yang tertinggi berada di Provinsi DKI Jakarta, yaitu sebesar $50.22 \%$, dengan status dalam dua periode tersebut sangat kritis. Sedangkan daerah yang mengalami perubahan kenaikan nilai surplus terendah yaitu Provinsi Jawa Tengah sebesar $2.36 \%$, status indeks kekritisan pada daerah tersebut pun masih berada pada kondisi belum kritis. Pulau Bali dalam dua periode mengalami kenaikan nilai indeks kekritisan air yaitu sebesar $72.53 \%$, yang mengakibatkan daerah tersebut mengalami perubahan status indeks kekritisan air, dari belum kritis menjadi sangat kritis. Peta indeks kekritisan air dengan model CSIRO pada tahun 1991 sampai dengan 2020 disajikan pada Gambar 3, dan pada tahun 2021 sampai dengan 2050 disajikan pada Gambar 4. Tidak berbeda halnya dengan model CSIRO, pada model MIROC perubahan terbesar indeks kekritisan air terjadi di Provinsi DKI Jakarta, yang mengalami kenaikan sebesar 52.03\% yang menyebabkan status daerah tersebut berada pada kondisi sangat kritis dalam jangka waktu tersebut. Sedangkan untuk wilayah yang mengalami kenaikan nilai indeks kekritisan air terendah yaitu Provinsi Jawa Barat sebesar $0.47 \%$, namun dengan perubahan yang terjadi tidak menyebabkan perubahan status indeks kekritisan air pada daerah tersebut yaitu masih berada pada status mendekati kritis. Berbeda halnya dengan Pulau Bali yang mengalami penurunan nilai indeks kekritisan air sebesar $8.67 \%$, namun dengan perubahan tersebut tidak mengubah status indeks kekritisan air dengan status mendekati kritis. Peta indeks kekritisan air dengan model CSIRO pada tahun 1991 sampai dengan 2020 disajikan pada Gambar 5, dan pada tahun 2021 sampai dengan 2050 disajikan pada Gambar 6 .

\section{Analisis Ekonomi Lingkungan}

Ketersediaan air wilayah
merupakan faktor penentu yang
digunakan dalam menghitung besarnya
kerugian defisit air. Defisit air suatu
wilayah perlu diperhitungkan, hal
tersebut bertujuan untuk mengantisipasi
terjadinya defisit yang melonjak di
kemudian hari.

Analisis ekonomi lingkungan diperhitungkan berdasarkan besarnya nilai defisit air yang terjadi pada suatu wilayah dalam jangka waktu pertahun yang dikalikan dengan nilai harga dasar air permukaan yang ditentukan oleh Kepmen PUPR No.12/KPTS/M/2019, dengan harga dasar air permukaan pada masing-masing daerah berbeda. Perhitungan mengenai analisis ekonomi lingkungan terdapat dua jenis model, yaitu dengan model CSIRO dan model MIROC. Hasil untuk nilai kerugian defisit air dengan model CSIRO pada tahun 1991 sampai dengan 2050 disajikan pada Tabel 6 . 


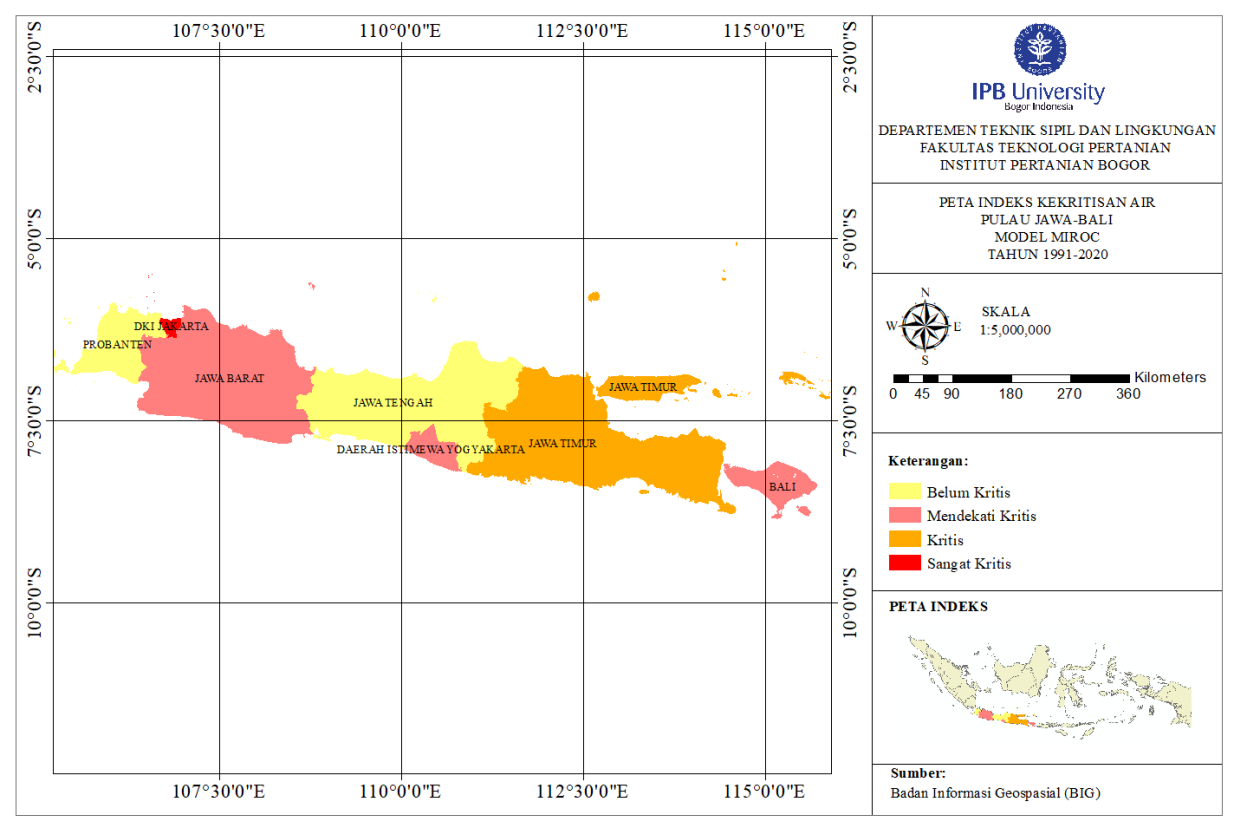

Gambar 3 Peta Indeks Kekritisan Air (IKA) Model CSIRO Pulau Jawa dan Bali Tahun 1991-2020

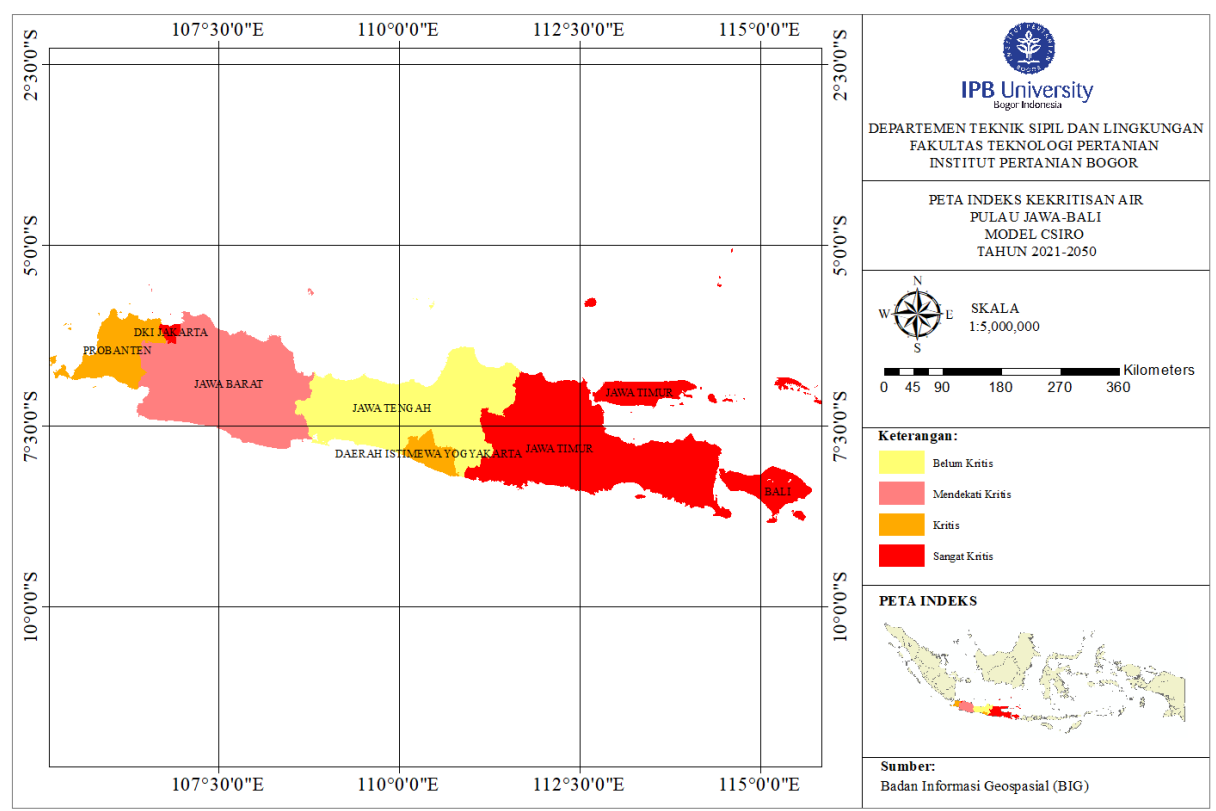

Gambar 4 Peta Indeks Kekritisan Air (IKA) Model CSIRO Pulau Jawa dan Bali Tahun 2021-2050 


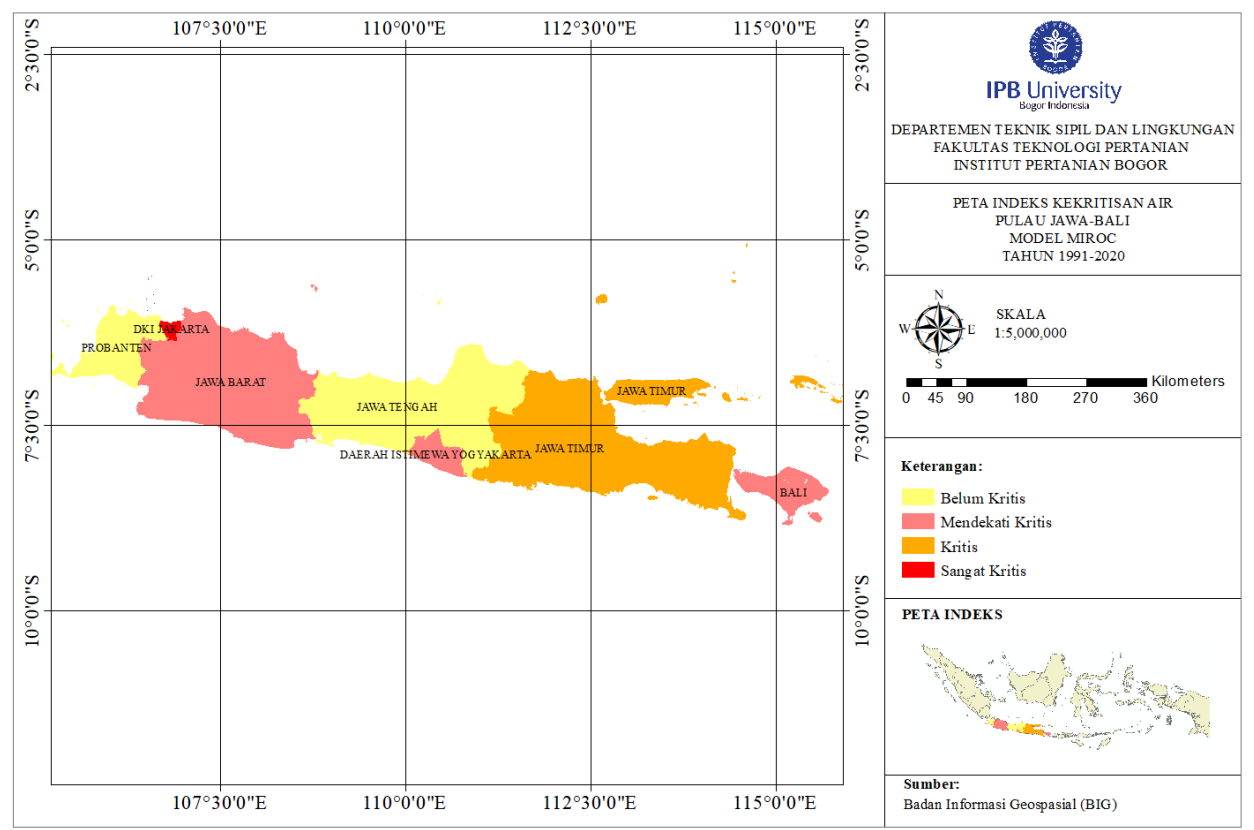

Gambar 5 Peta Indeks Kekritisan Air (IKA) Model MIROC Pulau Jawa dan Bali Tahun 1991-2020

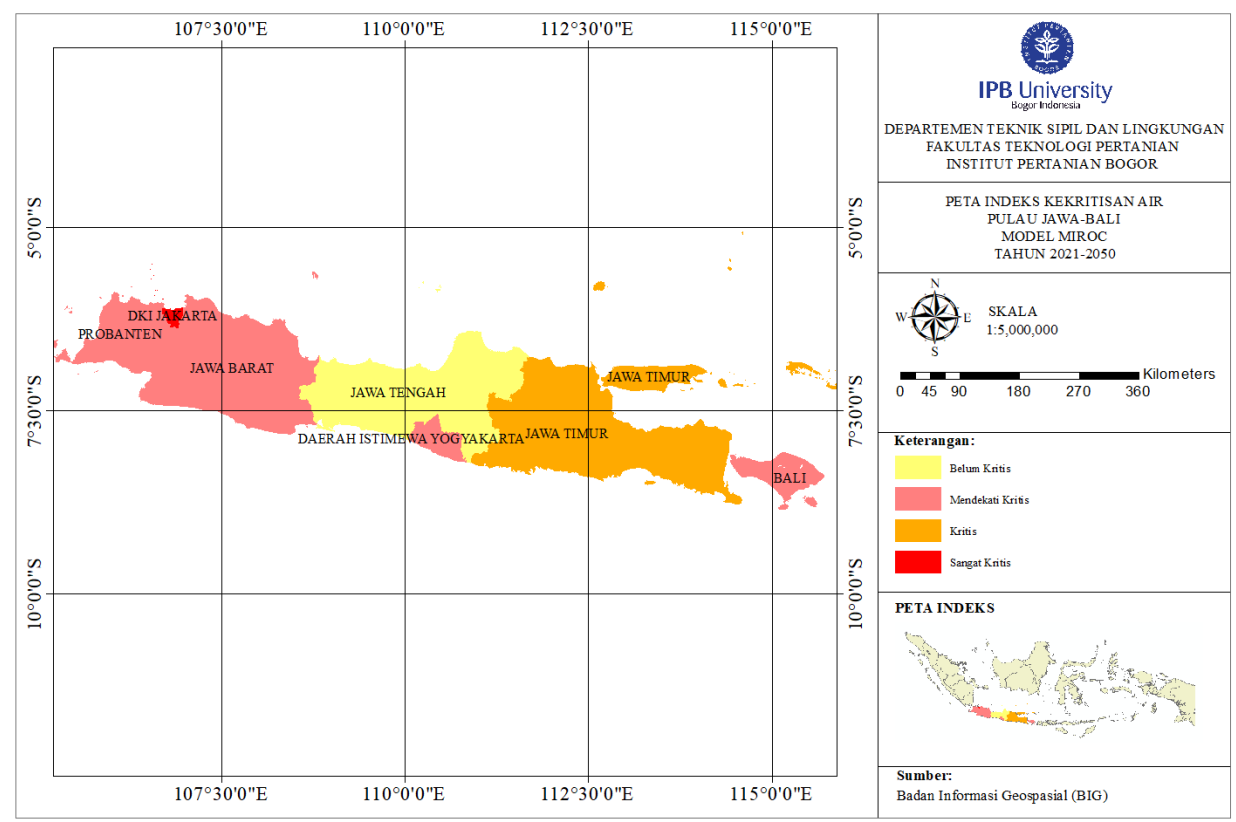

Gambar 6 Peta Indeks Kekritisan Air (IKA) Model MIROC Pulau Jawa dan Bali

Tahun 2021-2050 
Tabel 6 Nilai Kerugian Defisit Air Model CSIRO di Pulau Jawa dan Bali Tahun 1991-2050

\begin{tabular}{|c|c|c|}
\hline \multirow{2}{*}{ Provinsi } & \multicolumn{2}{|c|}{$\begin{array}{l}\text { Nilai Kerugian Defisit } \\
\text { Air (x10 } 12 \text { rupiah) }\end{array}$} \\
\hline & $1991-2020$ & $2021-2050$ \\
\hline DKI Jakarta & 1.13 & 1.20 \\
\hline Jawa Barat & 106.82 & 96.12 \\
\hline Jawa Tengah & 60.46 & 80.93 \\
\hline Jawa Timur & 6.27 & 7.93 \\
\hline DI Yogyakarta & 0.49 & 0.58 \\
\hline Banten & 11.45 & 22.96 \\
\hline Bali & 1.07 & 0.87 \\
\hline
\end{tabular}

Berdasarkan data yang disajikan pada Tabel 6 mengenai kerugian defisit air dengan model CSIRO yang dibagi ke dalam dua periode yaitu tahun 1991 sampai dengan 2020 dan tahun 2021 sampai dengan 2050, daerah yang memiliki kenaikan kerugian defisit air tertinggi yaitu berada di Provinsi Jawa Tengah, dengan perubahan kenaikan nilai defisit air dalam dua periode sebesar 20.48 triliun rupiah. Sedangkan untuk daerah yang mengalami penurunan nilai kerugian defisit air yaitu Provinsi Jawa Barat, yang mengalami penurunan sebesar 10.70 triliun rupiah. Pulau Bali dalam dua periode mengalami penurunan nilai kerugian defisit air sebesar 0.20 triliun rupiah.

Nilai kerugian defisit air dengan model MIROC disajikan pada Tabel 7. Nilai kerugian defisit air dengan model MIROC umumnya mengalami penurunan. Daerah yang mengalami penurunan nilai defisit air tertinggi yaitu Provinsi Jawa Tengah sebesar 3.94 triliun rupiah. Sedangkan untuk daerah di Pulau Jawa yang mengalami kenaikan nilai defisit air tertinggi dalam dua periode yaitu Provinsi Banten sebesar 3.26 triliun rupiah. Pulau Bali dengan model MIROC dalam rentang waktu tersebut mengalami penurunan nilai kerugian defisit air sebesar 0.09 triliun rupiah.

Tabel 7 Nilai Kerugian Defisit Air Model MIROC di Pulau Jawa dan Bali Tahun 1991-2050

\begin{tabular}{lcc}
\hline \multirow{2}{*}{ Provinsi } & \multicolumn{2}{c}{ Nilai Kerugian Defisit } \\
& \multicolumn{2}{c}{ Air (x10 rupiah $^{12}$} \\
\cline { 2 - 3 } & $1991-2020$ & $2021-2050$ \\
\hline DKI Jakarta & 0.53 & 0.42 \\
Jawa Barat & 30.65 & 30.71 \\
Jawa Tengah & 35.53 & 31.58 \\
Jawa Timur & 3.48 & 2.57 \\
DI Yogyakarta & 0.24 & 0.22 \\
Banten & 2.84 & 6.10 \\
Bali & 0.56 & 0.46 \\
\hline
\end{tabular}

\section{KESIMPULAN}

Perhitungan menggunakan dua periode yaitu tahun 1991 sampai dengan 2020 dan tahun 2021 sampai dengan 2050. Perubahan kenaikan rata-rata kebutuhan air yang terjadi di Pulau Jawa sebesar 7.24 miliar $\mathrm{m}^{3}$, sedangkan untuk Pulau Bali sebesar 0.05 miliar $\mathrm{m}^{3}$. Ratarata ketersediaan air dengan model CSIRO untuk wilayah Pulau Jawa mengalami penurunan sebesar 75.68 miliar $\mathrm{m}^{3}$ dan Pulau Bali mengalami penurunan sebesar 1.19 miliar $\mathrm{m}^{3}$. Ratarata ketersediaan air dengan model MIROC untuk wilayah Pulau Jawa mengalami kenaikan sebesar 18.50 miliar $\mathrm{m}^{3}$, dan Pulau Bali sebesar 0.67 miliar $\mathrm{m}^{3}$.

Neraca air dengan model CSIRO pada Pulau Jawa dalam rentang tahun 1991 sampai dengan 2020 dan tahun 2021 sampai dengan tahun 2050 mengalami perubahan penurunan nilai surplus dan kenaikan defisit sebesar $6.04 \%$, sedangkan untuk Pulau Bali mengalami penurunan nilai surplus dan kenaikan defisit sebesar $12.88 \%$. Model MIROC dalam rentang waktu tersebut untuk Pulau Jawa mengalami penurunan 
surplus dan kenaikan defisit sebesar 2.54\%, sedangkan untuk Pulau Bali mengalami kenaikan surplus dan penurunan defisit sebesar 3.38\%.

Besarnya nilai kerugian air pada tahun 1991 sampai dengan 2020 ke tahun 2021 sampai dengan 2050 dengan model CSIRO untuk wilayah Pulau Jawa mengalami kenaikan sebesar 3.85 triliun rupiah, sedangkan Pulau Bali mengalami penurunan sebesar 0.02 triliun rupiah. Model MIROC untuk wilayah Pulau Jawa mengalami penurunan sebesar 0.28 triliun rupiah, dan Pulau Bali pun mengalami penurunan nilai kerugian defisit air sebesar 0.09 triliun rupiah.

\section{DAFTAR PUSTAKA}

Amalia BI, Sugiri A. 2014. Ketersediaan air bersih dan perubahan iklim: studi krisis air di Kedungkarang Kabupaten Demak. Jurnal Teknik PWK. 3(2): 295-302

[BSN] Badan Standardisasi Nasional. 2015. SNI 6728 1:2015 tentang Penyusunan Neraca Spasial Sumber Daya Alam Bagian 1: Sumber Daya Air. Jakarta (ID): Badan Standardisasi Nasional

Haditiya FR, Projono S. 2018. Simulasi dampak perubahan iklim terhadap ketersediaan air tanaman tebu di wilayah Malang. Jurnal Tanah dan Sumberdaya Lahan. 5(1): 663672

Hermawan E. 2010. Pengelompokan pola curah hujan yang terjadi di beberapa kawasan P.Sumatera berbasis hasil teknik spektral. Jurnal Meteorologi dan Geofisika. 11(2): 75-85

[KepmenPUPR] Kementerian Pekerjaan Umum dan Perumahan Rakyat. 2019. Peraturan Menteri Pekerjaan Umum dan Perumahan Rakyat
Republik Indonesia Nomor 12 Tahun 2019 tentang Penetapan Harga Dasar Air Permukaan. Jakarta (ID): Kementerian Pekerjaan Umum dan Perumahan Rakyat

Kumalajati E, Budiadi, Sabarmudi S, dan Sudira P. 2015. Analisis Kebutuhan dan Ketersediaan Air di DAS Keduang Jawa Tengah. Jurnal Teknosains. 22(1): 1-80

Mawardi I. 2010. Kerusakan daerah aliran sungai dan penurunan daya dukung sumber daya air di Pulau Jawa serta upaya penanganannya. Jurnal Hidrosfir Indonesia. 5(2): 1-11

Nurlatifah A, Susanti I, Toersilowati L, Siswanto B. 2018. Sains dan Teknologi Atmosfer serta Aplikasinya di Benua Maritim Indonesia. Bandung (ID): Media Akselerasi

Perdinan. 2014. Perubahan iklim dan demokrasi: ketersediaan dan akses informasi iklim, peranan pemerintah, dan partisipasi masyarakat dalam mendukung implementasi adaptasi perubahan iklim di Indonesia. Jurnal Hukum Lingkungan. 1(1): 109-132

Rejekiningrum P. 2014. Dampak perubahan iklim terhadap sumberdaya air: identifikasi, simulasi dan rencana aksi. Jurnal Sumberdaya Lahan. 8(1): 1-18

Setiawan O. 2012. Analisis variabilitas curah hujan dan suhu di Bali. Jurnal Analisis Kebijakan Kehutanan. 9(1): 66-79

Thornthwaite CW. 1948. An approach toward a rational classification of climate. Geographical Review. 38(1): 55-94. 
Widayani P. 2016. Pemanfaatan citra worldvied-2 untuk analisis kepadatan penduduk dan proyeksi kebutuhan permukiman di Kota Magelang tahun 2012-2022. Jurnal Iptek Pertanahan. 6(2): 3954

Widiyono MG, Hariyanto. 2016. Analisis neraca air metode Thornthwaite Mather kaitannya dalam pemenuhan kebutuhan air domestik di daerah potensi rawan kekeringan di Kecamatan Triwulan Kabupaten Mojokerto. Jurnal Swara Bhumi. 1(1): 10-17

Wijayanti P, Noviani R, Tjahjono GA. 2015. Dampak perubahan iklim terhadap imbangan air secara meteorologis dengan menggunakan metode Thornthwaite Mather untuk analisis kekritisan air di Karst Wonogiri. Jurnal Geomedia. 12(1): $27-40$

Wiranta DO. 2019. Analisis neraca air Pulau Jawa menggunakan pendekatan supply-demand [skripsi]. Bogor (ID): Institut Pertanian Bogor 